\title{
INTEGRITAS SEORANG PENGKHOTBAH DAN KUALITAS KHOTBAH DALAM PEMBERITAAN FIRMAN TUHAN
}

\section{Sunarto}

\section{ABSTRAK}

Pada tataran apa pun di masyarakat ada kebutuhan yang kuat agar para pemimpin mereka memiliki hidup berintegritas. Masalah integritas dipandang sebagai tuntutan yang sangat mendasar dan mutlak bagi seorang pengkhotbah. Alkitab banyak membicarakan tentang dasar-dasar pentingnya intergritas pasca keberdosaan manusia yang pertama. Yesus adalah model pengkhotbah yang berintegritas secara sempurna. Injil kerajaan yang diberitakan oleh Yesus memanggil orang berdosa supaya bertobat di hadapan Allah. Apa yang diberitakan bukan untuk menyukakan kehendak manusia yang berdosa, tetapi supaya mereka hidup dalam pertobatan. Terpenuhinya aspek-aspek integritas bagi seorang pengkhotbah apabila dipadukan dengan kualitas khotbah akan menjadikan instrumen ini untuk menumbuhkan iman pendengar seperti yang dikendaki oleh Allah. Kebutuhan ini manjadi urgen karena antara integritas seorang pengkhotbah dengan kualitas khotbah dapat berimplikasi bagi pertumbuhan spiritual orang percaya.

\section{PENDAHULUAN}

Topik integritas sering menjadi pokok pembicaraan di berbagai kalangan masyarakat. Topik integritas menjadi mengemuka di berbagai pembicaraan masyarakat ditengah maraknya berbagai masalah yang dihadapi oleh berbagai organisasi swasta maupun pemerintahan. Dalam konteks bangsa Indonesia yang giat memberatas masalah koropsi, khususnya sejak pasca reformasi 1998, pemerintah sangat gencar untuk mengatasi masalah koropsi. Meskipun demikian masih banyak para pejabat pemerintah dan swasta yang tertangkap oleh Komisi Pemberatasan Koropsi (KPK) bahwa mereka melakukan koropsi. 
Permasalahan tersebut mencuatkan akan kebutuhan masalah integritas bagi seorang pemimpin di berbagai bidang dan jenjang. Salah satu upaya untuk mengatasi masalah tersebut dalam pemilihan kepala daerah atau para pejabat diwajibkan untuk menandatangani fakta integritas. Faktanya meskipun mereka sudah menandatangani fakta integritas masih saja ada pejabat yang tertangkap melakukan tindakan yang tercela, misalnya melakukan koropsi.

Gereja sebagai salah satu lembaga sosial di tengah masyarakat juga tidak lepas dari masalah integritas dari para pemimpin dan jemaatnya. Setiap gereja pasti menghendaki jemaatnya bisa bertumbuh secara rohani dengan baik dan bisa terlibat dalam pelayanan. Meskipun ada banyak pengkhotbah yang baik, namun khotbahnya belum tentu mendapatkan tempat di hati jemaat. Pendengar bukan hanya memperhatikan isi dan gaya penyampaian khotbahnya, tetapi apa yang dikhotbahkan sudahkah menjadi bagian dari hidupnya.

Mengapa integritas menjadi bagian penting bagi seorang pemimpin? Bukan hanya mereka yang menduduki jabatan publik, tetapi semua pemimpin membutuhkan intergritas? Pokok persoalanya, apakah masalah integritas seorang pengkotbah terkait langsung dengan kualitas khotbah. Tidak cukupkah seorang pengkhotbah itu mengandalkan kemampuan retorika, supaya khotbahnya menarik dan mudah dimengerti oleh pendengar? Kualitas khotbah seperti apakah yang bisa mempengaruhi kehendak para pendengar?

\section{INTEGRITAS SEORANG PENGKHOTBAH}

\section{Pengertian Integritas}

Pada tataran apapun di masyarakat ada kebutuhan yang kuat agar para pemimpin, di bidang apapun, apakah itu di bidang usaha, keagamaan, politik dan pemerintahan, mereka harus hidup berintegritas. Seperti yang dikatakan oleh Jonathan Lamb bahwa "integritas dipandang sebagai kualitas yang sangat mendasar dan penting dalam kepemimpinan."1

1Jonathan Lamb, Integritas Memimpin di Bawah Pengamatan Tuban (Jakarta: Literatur Perkantas, 2008), 24. 
Integritas merupakan aspek yang sangat diperhatikan di kalangan pegawai. Ketika mereka ditanyakan tentang apa yang mereka kagumi dari seorang pemimpin, maka integritas merupakan salah satu kualitas yang paling sering disebutkan. Integritas bagi seorang pemimpin berarti berarti bertindak jujur dan mempunyai sikap yang konsisten. ${ }^{2}$

Apabila kepemimpinan di bidang usaha, pendidikan, organisasi, yayasan sosial, politik dan pemerintahan menghendaki seorang pemimpin yang berintegritas, bagaimanakah kepemimpinan di lembaga gerejawi? Pemimpin gereja atau jemaat atau yang menyebut dirinya sebagai seorang hamba Tuhan, aspek integritas sangat penting bagi mereka. Kehidupan para pemimpin menjadi sorotan bagi jemaat yang dipimpinnya.

Apakah yang dimaksud dengan integritas? Integritas adalah mutu, sifat, atau keadaan yang menunjukkan kesatuan yang utuh sehingga memiliki potensi dan kemampuan, yang memancarkan kewibawaan serta adanya kejujuran. ${ }^{3}$ Integritas bisa diartikan keadaan yang utuh dan lengkap. Integritas mengandung arti bahwa seseorang mempunyai sifat yang lurus, jujur dan tulus. " Integritas adalah ketaatan yang teguh pada hukum nilainilai moral"5, ketika seorang pengkhotbah hidupnya tidak selaras dengan nilai-nilai moral maka bisa berakibat pada penilaian yang buruk dari orang yang dipimpinnya.

Seorang yang berintegritas berarti mempunyai konsistensi dalam berbicara dan dalam tindakannya. Jadi integritas seorang pengkhotbah adalah satu sikap hidup yang jujur, tulus, adil, dan mempunyai kasih kepada sesama, apa yang dikhotbahkan kepada pendengar itulah yang dilakukan kehidupan dalam sehari-hari.

\section{Dasar Alkitab Integritas}

${ }^{2}$ Ibid.

${ }^{3}$ Kamus Besar Bahasa Indonesi, Kamus Versi Online (Di unduh tanggal 16 Maret 2017).

4Jonathan Lamb, Integritas Memimpin di Bawah Pengamatan Tuban, 25-26.

5 Jerry Vines dan Jim Shaddix, Homiletika, Kuasa dalam Berkhotbah (Malang: Gandum Mas, 2009), 100. 
Alkitab sebagai dasar kehidupan orang percaya harus menjadi titik tolak integritas bagi seorang pengkhotbah. Perjanjian Lama dan Perjanjian Baru banyak membicarakan tentang dasar-dasar pentingnya intergritas. Sejak manusia yang pertama diciptakan, yaitu Adam dan Hawa, Allah menghendaki supaya manusia hidup taat seperti yang diperintahkan oleh Tuhan. Seperti yang dikatakan oleh Allah dalam Kejadian 2: 15-17 demikian:

TUHAN Allah mengambil manusia itu dan menempatkannya dalam taman Eden untuk mengusahakan dan memelihara taman itu. Lalu TUHAN Allah memberi perintah ini kepada manusia: "Semua pohon dalam taman ini boleh kaumakan buahnya dengan bebas, tetapi pohon pengetahuan tentang yang baik dan yang jahat itu, janganlah kaumakan buahnya, sebab pada hari engkau memakannya, pastilah engkau mati."

Ketika Allah memanggil Abram untuk meninggalkan kota Urkasdim menuju satu tempat yang dijanjikan, Allah juga memberikan perintah supaya Abram hidup sesuai dengan kehendak Tuhan. Allah mengatakan demikian: "Ketika Abram berumur sembilan puluh sembilan tahun, maka TUHAN menampakkan diri kepada Abram dan berfirman kepadanya: "Akulah Allah Yang Mahakuasa, hiduplah di hadapan-Ku dengan tidak bercela." Allah memanggil Abram untuk hidup "tidak bercela", yang berarti hidup secara "utuh atau menyatu". Ayat tersebut jelas menegaskan Abram dipanggil hidup berintegritas dihadapan Allah. Tidak bercela artinya hidup kudus karena tidak ada yang disembunyikan dihadapan Allah.

Ketika Allah memilih dan memanggil umat pilihannya, yaitu bangsa Israel, Allah memberikan perintah supaya mereka hidup berintegritas. Kehendak Allah supaya umat-Nya hidup berintegritas ditunjukkan Allah dengan memberikan hukum-hukum-Nya. Misalnya Sepuluh perintah Allah (Kel. 20:1-17) diberikan kepada umat-Nya sebagai tolok ukur dalam hubungannya dengan Allah dan sesama.

Pada era kerajaan, para pemimpin politik dan para nabi semua dipanggil supaya hidup sesuai dengan hukum-hukum Allah. Saul raja pertama bangsa Israel ketika tidak taat, Allah menggantikan orang lain, yaitu Daud. Para nabi pada era kerajaan Israel dipanggil oleh Allah untuk 
menyuarakan kebenaran dari Allah. Para nabi juga menegor para penguasa supaya mereka hidup benar dihadapan Allah.

Pada era Perjanjian Baru, hidup berintegritas ditampilkan oleh Yesus Kristus. Yesus adalah model pengkhotbah yang berintegritas secara sempurna. Injil kerajaan yang diberitakan oleh Yesus memanggil orang berdosa supaya bertobat dihadapan Allah. Apa yang diberitakan bukan untuk menyukakan kehendak manusia yang berdosa, tetapi supaya mereka hidup dalam pertobatan. Yesus sebagai pemimpin dan pengkotbah oreintasi pelayanannya hanya untuk mentaati kehendak Bapa, bukan untuk menyenangkan manusia yang berdosa.

Petrus dan Yohanes dua di antara rasul-rasul yang dipersiapkan oleh Yesus untuk menjadi seorang pemimpin jemaat, ketika mendapatkan tantangan berani mengatakan: "Silakan kamu putuskan sendiri manakah yang benar di hadapan Allah: taat kepada kamu atau taat kepada Allah. Sebab tidak mungkin bagi kami untuk tidak berkata-kata tentang apa yang telah kami lihat dan yang telah kami dengar" (Kis 4:19-20). Pemberita firman hanya tunduk kepada Allah ketika harus menghadapi tantangan, karena ia yakin siapa yang memberikan mandat pelayanannya.

Pemberita firman yang berintegritas juga ditunjukkan oleh kesaksian Paulus karena motivasi pelayanannya hanya dilandasi oleh kasih Kristus. Paulus sebagai pemberita firman konsisten untuk hidup berpadanan dengan Injil Kristus, ia tidak terpengaruh oleh pemberita firman yang palsu. Paulus tidak memungkiri jikalau ada orang memberitakan karena dengki dan perselisihan, mereka memberitakan Injill untuk kepentingan sendiri dan dengan maksud yang tidak iklas (Flp. 1:12-18).

\section{ASPEK-ASPEK INTEGRITAS SEORANG PENGKHOTBAH \\ Memiliki relasi yang intim dengan Tuhan}

Istilah ibadah pribadi digunakan untuk menggambarkan komunikasi yang akrab, antara Tuhan dengan anak-anak-Nya. Saat teduh atau devosi harian, ataupun namanya, setiap orang percaya harus menjadikannya sebagai prioritas utamanya. Melalui ibadah pribadi Tuhan bisa berbicara 
kepada orang beriman melalui firman-Nya. Orang percaya berbicara kepada-Nya melalui doa dengan segala masalah dan pergumulannya

Sangat logis jika ada orang beranggapan bahwa seorang pengkhotbah menghabiskan banyak waktu untuk berbagai hal yang berkaitan dengan persiapan khotbah, misalnya membaca Alkitab sewaktu mempersiapkan khotbah. Namun kesibukan tersebut kadang bisa menumpulkan kesadaran pengkhotbah mengenai perlunya bersekutu dengan Tuhan. Ada perbedaan mendasar antara bersekutu dengan Tuhan dan pelayanan kepada sesama.

Waktu ibadah pribadi bukanlah waktu untuk mempersiapkan khotbah, meskipun banyak sekali ide dan pemahaman yang bermanfaat pada saat itu. Ibadah secara pribadi merupakan saat mendengarkan suara Tuhan bagi kehidupan pribadi pengkhotbah. Dalam persekutuan pribadi merupakan hubungan yang mesra dengan Tuhan, ia mempelajari kasih Tuhan, janjijanji serta semua ajaran-Nya. Hubungan yang intim bersama merupakan hal yang sangat berharga untuk bertumbuh dalam Allah. ${ }^{6}$

Maka jelaslah bahwa titik tolak integritas bagi seorang pengkhotbah tidak dapat dipisahkan dalam hubungannya dengan Allah secara intim melalui persekutuan secara pribadi. Relasi yang intim bersama dengan Tuhan menunjukkan tingkat kedewasaan spiritualitas seseorang. Relasi yang intim bersama Tuhan menunjukkan ketergantungan seorang pengkhotbah akan jati diri dihadapan-Nya, bahwa ia seorang pemberita firman-Nya, bukan berita tentang pribadinya sendiri. Relasi yang demikian pada akhirnya akan menjadikan seorang pengkhotbah memiliki kepribadian yang matang, kuat, dan siap untuk menjadi saksi bagi Tuhan.

\section{Kemurnian dan ketulusan dalam melayani}

Setiap pendengar pasti merindukan kemurnian dari para pengkhotbah. Mereka mengetahui kalau pengkhotbah tidak tulus atau mencari keuntungan dari firman Allah. Seperti yang dikatakan oleh Paulus kepada jemaat di Korintus. "Sebab kami tidak sama dengan banyak orang lain yang mencari keuntungan dari firman Allah. Sebaliknya dalam Kristus kami

IIbid, 82-84. 
berbicara sebagaimana mestinya dengan maksud-maksud murni atas perintah Allah dan di hadapan-Nya" (Kej. 2:17).

Pengkhotbah yang mencari keuntungan menggunakan pesan firman untuk memperkaya diri dengan motivasi materi, tetapi pengkhotbah yang tulus meniru Kristus dalam melayani. Paulus juga mengontraskan antara ketulusan dengan ambisi kepentingan pribadi sendiri (Flp. 1:17) dan menyenangkan hati manusia (Kol. 3:22). ${ }^{7}$ Kepalsuan akan menjadi masalah dan tidak mudah diperbaiki jikalau itu sudah mengakar dalam kehidupan seseorang. Jadi kemurnian dan ketulusan bagi seorang pengkhotbah merupakan syarat mutlak bagi seorang pemberita firman.

Paulus kepada jemaat di Filipi juga mengingatkan adanya orang-orang yang memberitakan Injil, tetapi dengan motivasi yang palsu. Tampaknya ia memberitakan Injil, tetapi motivasinya bukan karena kemurnian dan ketulusan. Mereka memberitakan Injil karena dengki, mereka memberitakan Injil karena perselisihan, tetapi pengkhotbah berintegritas ia memberitakan Injil dengan maksud baik. Mereka yang memberitakan Injil karena dengki dan perselisihan, mereka melayani karena motivasi demi kepentingan diri sendiri dan dengan maksud yang tidak iklas. Meskipun demikian Paulus tidak terpengaruh dan tetap bersukacita di dalam Tuhan (Flp. 1:15-18).

Seorang pengkhotbah yang berintergritas harus menjaga kemurnian dan ketulusan dalam memberitakan firman-Nya. Tidak ada motif-motif yang tersembunyi yang dibungkus dengan kebenaran firman, padahal di dalamnya ada kebohongan. Apa yang disampaikan dan diajarkan kepada pendengar karena didasari dengan kemurnian dan ketulusan semata.

\section{Setia dan tanggung jawab dalam tugas}

Kesetiaan dan tanggung jawab merupakan dua aspek yang berdekatan serta tidak terpisahkan. Orang yang setia memungkinkan untuk bertanggung jawab akan tugas yang sudah diberikan. Berkaitan dengan

\footnotetext{
${ }^{7}$ Greg Scharf, Khotbah yang Transformatif (Jakarta: Yayasan Bina Kasih, 2013), 257.
} 
masalah integritas berarti pengkhotbah yang setia dan bertanggung jawab hanya menyampaikan pesan yang berasal dari Allah. Bukan menciptakan pesan sendiri dengan tujuan untuk menyenangkan para pendengar.

Seperti yang dikerjakan oleh Paulus tidak menciptakan pesannya sendiri. Paulus tidak menciptakan pesannya; dia menerimanya dan dengan setia meneruskannya kepada para pendengar. Dia tidak seperti nabi-nabi pada zaman Nabi Yeremia yang menyerah pada godaan untuk "yang menubutkan tipu rekaannya hatinya sendiri... menceritakan mimpinya" atau mencuri firman Allah (Yer. 23:25-32). Respons yang diberikan Tuhan adalah mengingatkan mereka akan persyaratan-Nya bagi pelayan-Nya: "Nabi yang beroleh firman-Ku, biarlah menceritakan firman-Ku itu dengan benar" (Yer. 23:28). ${ }^{8}$

Seorang pemberita firman yang berintegritas hanya mempunyai kesetiaan kepada Allah yang diimani sebagai pribadi yang telah memanggil dalam pelayanannya. Allah yang telah memberikan wahyu-Nya yang sudah dituliskankan di dalam Alkitab melalui proses inspirasi oleh Roh Kudus. Ia setia kepada kebenaran firman dan tidak berusaha membelokkan firman untuk kepentingan diri sendiri atau untuk menyenangkan para pendengar.

Dalam tataran praktis seorang pemberita firman mempunyai tanggung jawab yang tinggi setiap mendapatkan panggilan pelayanan. Tanggung jawab yang tinggi juga ditunjukkan untuk berusaha memenuhi jadwal pelayanan dan tidak digantikan oleh orang lain dengan alasan yang tidak kuat. Setia dan tanggung jawab tidak berlaku diskriminatif ketika sudah berkomitmen untuk menerima panggilan pelayanan, lalu menggantikan dengan orang lain, ketika mendapatkan panggilan pelayanan yang lebih besar jemaatnya atau lembaganya.

\section{Satu kata satu perbuatan}

Salah satu aspek penting dari integritas seorang pengkhotbah adalah satu kata satu perbuatan. Berbicara lebih mudah dari pada berbuat dalam tindakan. Sebaliknya orang yang berbuat tanpa berbicara, sudah memberikan pengaruh yang positif bagi orang melihat tindakannya. 
Perkataan bisa memberikan pengaruh kepada orang lain, demikian juga perbuatan seseorang juga bisa memberikan pengaruh kepada orang lain. Apabila dua aspek tersebut bisa digabung akan memberikan pengaruh yang lebih besar bagi organisasi, kelompok atau satu komunitas yang dipimpinnya.

Pengkhotbah yang berintegritas tidak bisa hanya mengandalkan kefasikan dalam berbicara, dan tidak bisa hanya mengandalkan teknik komunikasi yang tepat. Fasik berbicara dengan retorika yang memukau pendengar memang penting, tetapi apabila konsep atau gagasan yang diajarkan berlawanan dari kehidupan seorang pengkhotbah, maka khotbah yang disampaikan tidak bisa menggerakkan para pendengar. Satu kata satu perbuatan ibarat seperti satu mata uang yang memiliki dua sisi yang tidak terpisahkan, keduanya merupakan satu kesatuan yang utuh.

Seorang pengkhotbah sudah seharusnya menjadi contoh bagi para pendengar atau jemaat yang mendengarkan. Apa yang dikhotbahkan itulah yang seharusnya dihidupi atau dikerjakan dalam kehidupan kesehariannya. Gagasan, ide dan pesan-pesan khotbahnya bukan terhenti di atas mimbar, tetapi juga dilakukan dalam kehidupan sehari-hari.

Kegagalan satu prinsip tertentu tentang kebenaran firman, bisa mengurangi kualitas atau menghambat seorang pengkhotbah dalam memberitakan firman Tuhan itu topik tersebut. Demikian selanjutnya apabila seorang pemberita firman menjadi gagal untuk dua atau tiga prinsip kebenaran, akan semakin mengurangi intregitas dan kualistas suatu khotbah.

\section{Memiliki kerendahan hati dan bermegah dalam Allah}

Sikap kerendahan hati menunjukkan ketergantungan seorang pengkhotbah kepada pribadi Sang Pengutus. Ia berbicara memberitakan firman bukan karena mencari popularitas pribadi, tetapi terdorong karena panggilan ilahi. Sikap ini yang demikian akan menghindarkan pribadi pengkhotbah untuk membusungkan dada atau bersikap sombong kepada sesama. Lawan kerendahan hati adalah sikap sombong. Kerendahan hati 
artinya seseorang menyadari akan anugerah Allah, sebaliknya sikap sombong itu mengandalkan kekuatan sebagai seorang manusia.

Adakah tempat bagi pemberita firman untuk berbangga diri? Berbangga diri dengan membandingkan pelayanan dengan orang lain akan cepat berpuas diri. Pemberita firman kalau harus bermegah, bermegahkan dalam Allah, bukan bermegah dihadapan manusia. Bermegah di hadapan Allah artinya jikalau ia bisa memberitakan firman itu hanya karena pertolongan dan anugerah dari Allah.

Teladan yang sempurna dalam hal kerendahan hati adalah Tuhan Yesus sendiri.

... yang walaupun dalam rupa Allah, tidak menganggap kesetaraan dengan Allah itu sebagai milik yang harus dipertahankan, melainkan telah mengosongkan diri-Nya sendiri, dan mengambil rupa seorang hamba, dan menjadi sama dengan manusia. Dan dalam keadaan sebagai manusia, Ia telah merendahkan diri-Nya dan taat sampai mati, bahkan sampai mati di kayu salib (Flp. 2:6-8).

Tuhan Yesus juga mengajarkan: Orang yang meninggikan diri akan direndahkan, sebaliknya orang merendahkan diri akan ditinggikan (Luk. 14:11). Seorang pengkhotbah harus memililiki kerendahan hati karena ia hanyalah alat yang dipakai oleh Sang pengutus untuk panggilan yang suci.

\section{Komitmen dalam waktu}

Aspek lain yang penting untuk dipertahankan adalah mempunyai disiplin dalam menggunakan waktu kerja. Seorang pengkhotbah yang mempunyai integritas ia akan menghargai waktu yang diberikan oleh Tuhan. Pada jadwal yang sudah ditentukan ia akan datang dengan memperhitungkan waktu yang cukup sehingga tidak tergesa-gesa oleh karena waktu yang tidak cukup.

Jadwal yang sudah diatur dan disepakati tidak dengan mudahnya dibatalkan oleh karena suatu alasan yang tidak kuat. Pengkhotbah yang berintegritas akan menghargai waktu dengan mempersiapkan materi khotbah dalam waktu yang cukup. Materi khotbah yang dipersiapkan 
dengan baik jelas menuntut waktu yang cukup untuk merenungkan firman Tuhan dengan menerapkan prinsip-prinsip hermeneutik yang ketat.

Berkaitan dengan waktu seorang pengkhotbah juga harus memperhatikan seberapa lama ia akan menggunakan waktu dalam berkhotbah. Bukan dengan mudahnya mengklaim karena atas nama Roh Kudus sehingga ia berkhotbah begitu lama, padahal durasi waktu sudah diberitahukan sebelumnya. Durasi khotbah yang lama, ditambah dengan pola penyampaian yang membinggungkan justru menambah kebosanan bagi jemaat. Durasi khotbah yang lama bisa dimungkinkan, apabila dari awal sudah diatur karena acara tertentu yang menuntut waktu yang lebih lama.

\section{KuALITAS KHOTBAH DALAM PEMBERITAAN FIRMAN}

\section{Pengertian Kualitas Khotbah}

Kualitas kotbah yang baik bukan diukur seberapa banyak khotbah itu dihadiri oleh para pendengar. Kualitas khotbah yang baik juga bukan diukur khotbah disampaikan dalam gereja yang besar atau gereja yang kecil. Kualitas khotbah juga bukan diukur dari banyak sedikitnya penggunaan bahasa asing atau bahasa aseli Alkitab. Kualitas khotbah yang baik berbicara tentang kualitas atau bobot materi dan penerapan komunikasi yang tepat kepada para pendengar.

Kualitas dapat diartikan: 1 tingkat baik buruknya sesuatu; kadar; 2 derajat atau taraf; mutu. Misalnya: kualitas pribadi yang baik merupakan bentuk tingkah laku yang baik seseorang sebagai warga masyarakat atau warga negara yang dapat dijadikan teladan dalam hidup bermasyarakat dan bernegara. ${ }^{9}$ Kualitas khotbah menunjuk pada pengertian tentang tingkat

${ }^{9}$ Tim Penyusun Kamus Pusat Pembinaan dan Pengembangan Bahasa, Kamus Besar Bahasa Indonesia (Jakarta: Balai Pustaka), 467. 
baik buruknya sebuah khotbah yang disampaikan oleh seorang pengkhotbah. Kualitas khotbah yang baik adalah sebuah khotbah yang disampaikan oleh seorang pengkhotbah dari sisi materi memiliki tingkatan mutu yang baik dan dari sisi penyampaian (komunikasi) dapat dimengerti oleh para pendengarnya.

\section{Ciri-ciri Khotbah yang Berkualitas}

Bertanggung jawab secara hermeneutika

Khotbah yang berbobot atau berkualitas tidak bisa dipisahkan dari penerapan hermeneutika yang bertanggung jawab. Mengapa khotbah yang berkualitas tidak bisa dipisahkan dengan penerapan hermeneutika? Hermeneutika adalah ilmu untuk menafsirkan teks atau suatu dukumen. Hermeneutika ialah ilmu yang menetapkan, prinsip, aturan dan patokan yang menolong untuk mengerti atau mengartikan salah satu karya atau dokumen dari jaman sekarang atau terutama dari jaman dahulu. ${ }^{10}$ Seorang pengkhotbah apabila ia mempersiapkan bahan khotbah dengan menggunakan hermeneutika yang ketat dan bertanggung jawab pasti menghasilkan pesan-pesan yang sesuai dengan makna yang tertulis dalam teks (Alkitab).

Kualitas khotbah berhubungan erat dengan hermeneutika karena akan memampukan seseorang untuk beralih dari teks kepada konteks. Hermeneutika juga mengizinkan makna yang diinspirasikan Allah dari firman itu untuk berbicara pada hari ini dengan kesegaran dan kekuatan yang sama seperti sebelumnya di dalam latar belakang aselinya. Lebih dari pada itu, para pengkhotbah harus memberitakan firman Allah, bukan pendapat-pendapat religius mereka yang subyektif. Hanya hermeneutika yang ditentukan dengan jelas yang dapat membuat seseorang sesuai dengan teks. ${ }^{11}$

${ }^{10}$ Sejarah Alkitab Indonesia, Situs ini dibuat oleh Yayasan Lembaga SABDA (YLSA) 2003-2016. Di Unduh, tanggal 13 Nopember 2016.

${ }^{11}$ Grant R. Osborne, Spiral Hermeneutika, Pengantar Komprehensif bagi Penafsir Alkitab (Surabaya: Momentum, 2012), 4. 
Kewajiban utama dan terpenting pada saat seorang pengkhotbah membaca Alkitab adalah menemukan apa yang sebenarnya disampaikan oleh Roh Kudus ketika Ia mengilhami penulisan suatu kitab (Alkitab). ${ }^{12}$ Langkah ini dalam ilmu Homiletika lebih dikenal sebagai eksposisi. Eksposisi dapat "didefinisikan sebagai proses membeberkan nas Alkitab secara sedemikian rupa, sehingga makna aselinya bisa dihubungkan dengan kehidupan para pendengarnya saat itu."13

Kebenaran-kebenaran firman Allah itu dalam, luas, tinggi dan lebar, karena pekerjaan untuk mengungkapkan makna aseli dari teks tertentu kadang begitu rumit dan menuntut kerja keras. Pengkhotbah dapat memenuhi tanggung jawab yang besar ini hanya jika mau mengembangkan dan menerapkan suatu hermeneutika yang konsisten. ${ }^{14}$ Berkhotbah dengan menerapkan prinsip-prinsip hermeneutika berarti seorang pengkhotbah tidak seharusnya menafsirkan setiap nas Alkitab menurut kemauan sendiri, tetapi menafsirkan ayat Alkitab menurut kaidah yang benar. Menerapkan hermeneutika yang bertanggung jawab berarti menghindari penafsiran dengan cara memaksa nas Alkitab di luar konteks ayat dan latar belakangnya.

\section{Memberitakan kebenaran dari Allah dan bukan untuk menyenangkan manusia semata}

Khotbah yang berkualitas dapat tercermin dari pesan khotbah yang disampaikan oleh seorang pengkhotbah. Materi khotbah bukan disusun berdasarkan kesenangan atau kepentingan pribadi. Materi yang disampaikan hanya memberitaan pesan kebenaran yang ditemukan di dalam Alkitab. Tugas pengkhotbah adalah menggali dan berusaha menemukan kebenaran dari wahyu Allah seperti yang sudah ditulis di dalam Alkitab.

12Jerry Vines dan Jim Shaddix, Homiletika, Kuasa Dalam Berkhotbah (Malang: Gandum Mas, 2009), 127.

13Ibid, 38.

${ }^{14}$ Grant R. Osborne, Spiral Hermeneutika, Pengantar Komprehensif bagi Penafsir Alkitab, 5. 
Meskipun penulisan Alkitab ditulis pada masa lampau dengan jarak ribuan tahun yang lalu, nilai kebenarannya tidak pernah berubah. Kebenaran selalu benar kapanpun dan di manapun ditemukan. Kebenarankebenaran teologis besar yang berbicara kepada hati orang-orang dalam Alkitab juga berbicara kepada hati kita. Ketika pengkhotbah menemukan semua kebenaran abadi ini, nyatakan semuanya dalam prinsip-prinsip yang berlaku pada kebutuhan semua orang di segala zaman, termasuk kebutuhan-kebutuhan para pendegar pada saat ini. ${ }^{15}$

Tugas pengkhotbah bukan menyampaikan apa yang ingin didengar dari para pendengar, tetapi apa yang Allah katakan dan bagaimana kaitannya dengan mereka. Pengkhotbah juga perlu memutuskan bagian mana dari Alkitab yang seharusnya diuraikan pada saat itu. Tujuannya supaya bisa meninjau kembali pelayanan seperti yang Paulus lakukan dan katakan, "Sebab aku tidak lalai memberitakan seluruh maksud Allah kepadamu (Kis 20:27).

Pengkhotbah harus membiarkan Alkitab sendiri untuk terus menerus memperbarui pemahamannya, berkaitan dengan pandanan dunia, asumsi-asumsi budaya, dan memberikan kepada pengkhotbah dalam sudur pandang Allah. Pesan khotbah yang berkualitas harus bertekad membiarkan Alkitab untuk mengatur agenda khotbah karena yakin bahwa Allah sendiri telah memerintahkannya. Wahyu Allah dipahami secara tepat dan diberitakan dalam kuasa Roh Kudus sebagai cara untuk mencapai apa yang Allah inginkan bagi jemaat-Nya. ${ }^{16}$

\section{Mempunyai struktur khotbah yang jelas}

Sekalipun tidak ada satu bentuk khotbah yang baku, namun bukan berarti sebuah khotbah disampaikan tanpa format atau bentuk yang tidak jelas. Khotbah sebaiknya menggunakan struktur yang baik. Struktur khotbah berkaitan dengan cara sesuatu disusun atau dibangun. Ibarat seperti membangun rumah memerlukan pondasi, tembok, pintu, jendela 174-175.

15Jerry Vines dan Jim Shaddix, Homiletika, Kuasa Dalam Berkhotbah,

${ }^{16}$ Greg Scharf, Khotbah yang Transformatif, 159-160 
sampai dengan atapnya. Tanpa struktur yang logis dan jelas, suatu khotbah tidak akan berpengaruh dan berkuatan sebagaimana mestinya. Bahkan tidak menutupi kemungkinan tanpa struktur khotbah yang baik dapat menimbulkan kebingungan pendengar. Untuk menghindari kebingungan tersebut, pengkhotbah harus memahami dan memerlukan struktur khotbah yang baik. ${ }^{17}$

Kitab-kitab yang ada di Alkitab ditulis dalam konteks budaya manusia yang sedang berkembang pada zamannya. Dari segi kesusasteraan teks-teks kitab Suci ditulis juga menggunakan bentuk sastra yang berkembang pada zamannya. Maka dilihat dari muatan isi pesannya setiap teks menggunakan susunan, misalnya ada bagian pendahuluan, pesan utama dan bagian penutup. Tugas seorang pengkhotbah adalah bagaimana menemukan pesan utama dari sebuah teks dan maknanya bagi pendengar di era sekarang.

Maka khotbah yang benar dan berkualitas adalah khotbah yang alkitabiah. Khotbah alkitabiah adalah khotbah yang menempatkan Alkitab pada pusatnya, khotbah yang menyingkapkan kekuatan dan kekuasaan Alkitab. Sekalipun seorang pengkhotbah itu mengkhotbahkan tentang topik atau tema tertentu. Khotbah yang alkitabiah adalah khotbah yang menguraikan suatu perikop Alkitab. ${ }^{18}$ Apapun tema yang mau dibahas dan disampaikan kepada pendengar, sebuah khotbah yang disusun dengan menggunakan sebuah struktur yang baik akan menolong para pendengar untuk memahaminya.

\section{Pondasi atau dasar khotbah adalah memberitakan firman Allah}

Dalam ilmu homiletika diajarkan berbagai bentuk atau model khotbah. Ada tiga bentuk khotbah yang banyak dibicarakan dalam ilmu khotbah, yaitu: khotbah topikal, tekstual dan ekspositori. Istilah apa pun yang digunakan oleh seorang pengkhotbah, seorang pengkhotbah harus mengkhotbahkan firman Tuhan. Seorang pengkhotbah semakin mengkhotbahkan firman Tuhan, khotbah itu akan semakin penuh kuasa.

${ }^{17}$ Jeerry Vines dan Jim Shaddix, Homiletika, Kuasa dalam Berkhotbah (Malang: Gandum Mas, 2009), 203-204.

18Jonathan Lamb dkk, Memahami dan Berbagi firman Tuban, 186. 
Mungkin ada sebagian dari pendengar yang merasa bosan ketika mereka mendengarkan berita dari Alkitab, namun jawaban terhadap masalah ini bukan berarti harus meninggalkan Alkitab, tetapi bagaimana seorang pengkhotbah meningkatkan kualitas isinya khotbahnya. ${ }^{19}$

Pondasi atau dasar khotbah bukan berasal surat kabar, kata orang terkenal, dari youtoube, media sosial atau televisi, tetapi berasal dari wahyu Allah yang sudah dituliskan dalam Alkitab. Ada seorang pengkhotbah yang mengawali khotbah dengan membaca ayat Alkitab setelah selesai pembacaan Alkitab ditutup dan tidak pernah dibuka lagi sampai khotbah berakhir. Khotbah yang demikian bukan memberitakan firman Tuhan, tetapi Alkitab dijadikan sebagai batu loncatan sebelum ia menyampaikan pendapat sendiri.

Khotbah yang memberitakan firman Allah bukan menjadikan Alkitab sebagai pelengkap. "Alkitab diperlakukan sebagai pemicu untuk memperoleh cerita dari para pendengar, dan bukan sebagai firman yang memiliki otoritas dari Allah."20 Tugas pengkhotbah bukan bukan menyampaikan apa yang ingin didengar para pendengar, tetapi menyampaikan apa yang Allah katakan tentang mereka. Seperti yang dikatakan oleh Paulus, "Sebab aku tidak lalai memberitakan seluruh maksud Allah kepadamu" (Kis 20:27). ${ }^{21}$

Khotbah yang berkualitas berarti pengkhotbah membaca ayat Alkitab dan menjelaskan ayat-ayat tersebut (eksposisi) berdasarkan prinsip-prinsip hermeneutika sehingga para pendengar mengerti apa yang maksud dari firman Tuhan tersebut. Ayat atau perikop Alkitab itulah yang harus dijelaskan kepada para pendengar. Ayat atau perikop harus diuraikan karena Alkitab adalah pondasi atau dasar dari seorang pemberita firman.

\section{Materi khotbah yang benar dan komunikasi yang tepat}

${ }^{19}$ Kenton C. Anderson, Choosing to Preach Deklaratif, Pragmatis, Naratif, Visioner, Integratif (Malang: Gandum Mas, 2010), 39.

${ }^{20}$ Greg Scharf, Khotbah yang Transformatif, 158-159.

${ }^{21}$ Ibid, 159. 
Salah satu ciri khotbah yang berkualitas tidak bisa dipisahkan dari materi khotbah yang benar. Materi khotbah yang benar harus bersumber dari Alkitab dan ditafsirkan dengan menggunakan pendekatan hermeneutika yang ketat dan konsisten. Materi khotbah yang benar bukan menyampaikan pendapat-pendapat pribadi yang subyektif, oleh karena keinginan manusia, tetapi menyampaikan apa yang menjadi kehendak Allah yang bersumber dari Alkitab.

Khotbah yang berkualitas harus didukung oleh dua aspek, yaitu: materi khotbah yang benar dan penyampaian yang baik. Materi yang berbobot akan menyelamatkan penyampaian yang lemah, sedangkan penyampaian khotbah yang baik dapat menyelamatkan materi khotbah yang lemah. Khotbah yang berkualiatas harus menggabungkan dua aspek tersebut, yaitu materi khotbah yang berbobot dan penyampaian khotbah yang baik.

Komunikasi khotbah yang tepat berarti khotbah yang disampaikan bukan membinggungkan pendengar, tetapi menolong mereka sehingga mengerti apa yang disampaikan. Seperti yang apa yang dikatakan oleh Kenton C. Anderson demikian: "Kedalaman sebuah khotbah terletak pada kesederhanaannya namun dimengerti secara mendalam bukan pada kesulitannya untuk dimengerti dan ketidakberaturannya."22

\section{IMPLIKASI INTEGRITAS PENGKOTBAH DAN KUALITAS KHOTBAH BAGI PENDENGAR}

\section{Menimbulkan Minat yang Tinggi bagi Pendengar}

Ketika jemaat datang ke gereja salah satu di antaranya mereka ingin mendengarkan firman Tuhan. Kerinduan untuk mendengarkan firman Tuhan akan terhalang apabila khotbah yang disampaikan seorang pengkhotbah tidak memiliki bobot, baik dari materi khotbahnya maupun pola penyampaian yang lemah. Akibatnya jemaat tidak memiliki minat yang tinggi untuk mendengarkan suatu khotbah. Implikasi selanjutnya para

\footnotetext{
${ }^{22}$ Kenton C. Anderson, Choosing to Preach Deklaratif, Pragmatis, Naratif, Visioner, Integratif, 112.
} 
pendengar menjadi bosan atau bahkan menjadi mengantuk. Seperti apa yang dikatakan Robinson demikian: "Khotbah-khotbah yang membosankan dan hambar bukan menyebabkan mata menjadi berat dan kepala yang terangguk-angguk, mereka juga menghancurkan kehidupan dan pengharapan" (H.W. Robinson dan T.W. Robinson, It's All In How Tell It)

Minat pendengar untuk mendengarkan khotbah bisa menjadi terhambat oleh karena dua aspek yang bisa berpengaruh. Integritas pengkhotbah yang tercela bisa berpengaruh besar terhadap minat pendengar dalam mendengarkan suatu khotbah. Sekalipun pengkhotbah memiliki kemampuan orasi yang fasih dalam berbicara, tetapi ketika para pendengar melihat apa yang disampaikan tidak sesuai dengan pola hidupnya, maka suatu khotbah tidak memiliki dampak yang besar bagi pendengar.

Aspek kedua yang bisa berpengaruh besar adalah pola penyampaian khotbah yang jelas dan relevan. Aspek ini penting karena integritas pengkhotbah akan menjadi lengkap jika disertai pola penyampaian yang baik. Khotbah yang jelas artinya khotbah yang disampaikan bukan membingungkan para pendengar. Sedangkan khotbah yang relevan adalah khotbah yang bisa menjawab situasi dan kondisi yang dihadapi oleh para pendengar. Khotbah yang bisa menjawab sesuai dengan kebutuhan dari pendengar bukan berarti khotbah yang disampaikan itu mengorbankan kebenaran untuk menyenangkan jemaat, tetapi memberikan jawaban dalam terang firman Tuhan.

Tugas pengkhotbah adalah memperlengkapi diri secara pribadi supaya memiliki kepribadian yang berintegritas dan terus memperlengkapi diri untuk pemberita firman yang berkualitas. Apabila dua aspek ini sudah dikerjakan, tetapi para pendengar masih memiliki minat yang rendah terhadap suatu khotbah, barangkali tanggung jawab berikutnya terletak pada para pendengar atau jemaat. Apabila keduanya bisa dipersiapkan dengan baik atau seimbang, maka minat yang tinggi terhadap suatu khotbah akan menjadi sebuah ibadah yang diperkenan oleh Allah.

\section{Menolong Pendengar untuk Memahami firman Allah}


Faktor keberterimaan dalam suatu khotbah harus menjadi langkah awal sebelum pendengar melakukan suatu khotbah yang disampaikan oleh seorang pengkhotbah. Namun sasaran tersebut akan menjadi terhambat, jikalau dalam penyampaian suatu khotbah para pendengar tidak mengerti atau tidak memahami firman Tuhan yang disampaikan. Jadi apabila integritas pengkhotbah dan kualitas khotbah bisa terpenuhi maka ketika mendengar mendengarkan suatu khotbah akan menolong mereka untuk memahami firman Allah.

Kebenaran firman Allah bisa difahami oleh orang percaya tidak terlepas dari kuasa Roh Kudus yang memampukan manusia bisa memahami firmanNya. Allah dalam membukakan kebenaranNya juga bisa memakai hambaNya sehingga jemaat bisa mengerti firman-Nya. Roh Kudus menerangi seorang Pengkhotbah dan para pendengar untuk melihat kebenaran rohani. Dalam konteks ini, Roh Kudus dapat bertindak sebagai guru yang mengajarkan kebenaran rohani. Orang yang belum menerima keselamatan di dalam Kristus tidak dapat memahami kebenaran rohani. Apabila seseorang sudah bertobat, Roh Kudus yang mendiami orang percaya akan menjadi Penolong untuk mengajar atau menerangi sehingga orang tersebut mengerti kebenaran rohani. ${ }^{23}$

Jadi tugas seorang pengkhotbah adalah mempersiapkan materi khotbah dengan baik. Materi yang khotbah yang baik tercermin dari materi yang berbobot oleh pendekatan hermeneutika yang bertanggung jawab. Materi yang berbobot dikomunikasikan dengan tepat sehingga para pendengar dapat memahami firman Tuhan dengan mudah, dan bukan sebaliknya menjadi bingung.

\section{Membantu Pertumbuhan Iman bagi Pendengar}

Ketika khotbah diberitakan tujuan akhirnya bukan untuk meninggikan seorang pengkhotbah. Khotbah diberitakan kepada para pendengar dengan tajuan membantu mereka supaya bertumbuh dewasa di dalam Tuhan. Pendengar sebagai orang percaya bisa bertumbuh secara rohani, mereka

\footnotetext{
${ }^{23}$ L. Towns, The Names of The Holy Spirit (Yogyakarta: Penerbit Andi, 2009), 21.
} 


\section{6 | INTEGRITAS SEORANG PENGKHOTBAH}

bisa menjadi merid-murid Kristus seperti yang dikehendaki oleh Allah. Mereka bisa bertumbuh dewasa seperti yang dikatakan oleh Paulus dalam doanya demikian: "sehingga hidupmu layak† di hadapan-Nya serta berkenan kepada-Nya† dalam segala hal, dan kamu memberi buah dalam segala pekerjaan yang baik dan bertumbuh dalam pengetahuan yang benar tentang Allah," (Kol 1:10).

Sekalipun ada krisis khotbah untuk berbagai kasus tertentu, oleh karena mimbar disalahgunakan oleh pengkhotbah yang menyimpang, akan tetapi Allah tetap bisa memakai para hamba-Nya yang takut Tuhan. Alexander mengatakan demikian: "Khotbah akan jadi alat yang paling mulia yang dapat mempengaruhi kebanyakan orang modern. Karena khotbah adalah cara Allah. Allah akan memuliakan khotbah dengan cara-Nya. Karena orang-orang yang membangunkan satu zaman di mana pun di Barat atau di Timur, dan dari zaman dulu sampai sekarang, semuanya adalah pengkhotbah firman Allah yang besar". ${ }^{24}$

Seorang pengkhotbah bukanlah seorang pribadi yang sempurna karena masih memiliki kelemahan-kelemahan, tetapi berita firman yang disampaikan bisa dipakai oleh Allah. Sama seperti para nabi di era Perjanjian Lama, demikian juga para rasul, dan orang-orang percaya di era Perjanjian Baru, mereka bisa dipakai oleh Allah untuk menjad alat Tuhan. Para nabi dan rasul juga bukan pribadi yang sempurna, mereka masih memiliki kelemahan, tetapi Allah bisa memakai mereka untuk menyampaikan firman-Nya. Para pengkhotbah di masa kini pun juga bisa dipakai oleh Allah untuk menyampaikan firman-Nya sehingga para pendengar bisa bertumbuh dalam iman.

\section{Pendengar Melakukan Perintah Tuhan}

Barangkali setiap pengkhotbah ketika selesai menyampaikan khotbah lalu mendapatkan ucapan selamat atau mendapatkan komentar dari penedengar yang memberikan apresiasi bahwa khotbah yang disampaikan

${ }^{24 D}$.W. Lee, Khotbah Ekspositori yang Membangunkan Pendengar, Krisis dan Kesempatan Mimbar Masa Kini (Bandung: Lembaga Literatur Baptis, 2002), 350-351. 
sangat baik, berbobot dan sangat memberkatinya, respon yang demikian tentunya bisa membuat pengkhotbah menjadi senang. Betapapun kotbah dikatakan baik, berbobot dan memberkati bagi pendengar, tetapi apabila kotbah itu tidak mendorong atau menggerakkan pendengar untuk menjadi pelaku firman, maka sebuah kotbah tersebut tidak dapat dikatakan sebagai kotbah yang berhasil.

Berita firman yang diberikan kepada manusia dengan tujuan supaya orang-orang percaya melalukan apa yang menjadi kehendak Tuhan. Maka sebuah khotbah apabila tidak menggerakan pendengar untuk melakukan firman tidak dapat dikatakan menjadi kotbah yang dapat mencapai sasaran. Sasaran yang dimaksud adalah pendengar bisa memahami dengan kebenaran firman yang tertulis di dalam Alkitab. Kebenaran yang difahami oleh pendengar bukan hanya member kepuasan secara intelektual dan emosi, tetapi jiwanya digerakkan secara sadar untuk melakukan firman dalam hidup kesehariannya.

Kebenaran isi khotbah bukan hanya untuk memberi kepuasan secara intelektual saja, tetapi mengajak pendengar untuk menyatakan atau melakukan dalam kehidupan yang riil ditengah-tengah lingkungan dan masyarakat luas. Kualitas khotbah bukan terhenti diatas mimbar sehingga para pengkhotbah cukup puas dan merasa bangga kalau khotbah mendapatkan tempat dihati pendengar. Kualitas khotbah yang utuh harus juga tercermin dari dorongan pendengar untuk menjadi pelaku firman.

\section{PENUTUP}

Integritas seorang pengkhotbah menjadi kebutuhan mutlak bagi seseorang yang terpanggil untuk menyampaikan pemberitaan firman. Integritas berkaitan dengan mutu, sifat, atau keadaan yang menunjukkan kesatuan yang utuh sehingga seorang pengkhotbah memiliki potensi dan kemampuan,yang memancarkan kewibawaan serta adanya kejujuran. Seorang pengkhotbah yang berintegritas memiliki ketaatan yang teguh pada hukum dan nilai-nilai moral, sehingga pemberitaan khotbahnya selaras dengan kehidupannya. Apa yang disampaikan tidak diragukan dan dipertanyakan oleh pendengar karena tersandung oleh faktor kepribadian seorang pengkhotbah. 
Sedangkan kualitas khotbah yang baik adalah sebuah khotbah yang disampaikan oleh seorang pengkhotbah dari sisi materi memiliki tingkatan mutu yang baik dan dari sisi penyampaian dapat dimengerti oleh para pendengarnya. Apa yang disampaikan merupakan proses penggalian secara bertanggung jawab. Jadi antara integritas seorang pengkhotbah dan kualitas khotbah merupakan dua aspek penting yang perlu dipadukan dalam pelayanan pemberitan firman. Keduanya bisa berimplikasi besar terhadap sikap dan respon pendengar. Khotbah bukan hanya alih transfer pengetahuan teologis, tetapi memberi dorongan, kesadaran, keinsafan dan perubahan hidup seperti yang dikehendaki oleh Allah.

Sunarto, menyelesaikan program Sarjana Muda Teologi di Sekolah Tinggi Teologi Injili Efrata (STTI Efrata) Sidoarjo, Sarjana Teologi dan Master of Art di Sekolah Tinggi Teologi Injili Abdi Allah (STT IAA) di Pacet Mojokerto. Magister Teologi diperoleh dari Sekolah Tinggi Baptis Indonesia (STBI) di Semarang. Sekarang melayani sebagai dosen dan Ketua Program Studi di ST'T SAPPI Ciranjang Cianjur. 